DEVELOPMENT OF MANAGEMENT

AND ENTREPRENEURSHIP METHODS

ON TRANSPORT, № 3 (76), 2021
РОЗВИТОК МЕТОДІВ

УПРАВЛІННЯ ТА ГОСПОДАРЮВАННЯ

НА ТРАНСПОРТІ, № 3 (76), 2021
УДК 338.48:378

JEL I 20, J 21, L 83

DOI 10.31375/2226-1915-2021-3-115-128

SOFT SKILLS

ЯК КЛЮЧОВІ КОМПЕТЕНТНОСТІ

ПЕРСОНАЛУ ТУРИСТИЧНИХ

ПІДПРИЕМСТВ ТА ЇХ РОЗВИТОК

ЧЕРЕЗ ОСВІТНІ ПРОГРАМИ У ЗАКЛАДАХ ВИЩОЇ ОСВІТИ

І.В. Савельєва

д.е.н., професор, завідувач кафедри

«Підприємництво та туризм»

Одеський національний морський університет, Одеса, Украӥна

Анотація. У статті розглянуті найбільш важливі для випускників ЗВО в сфері туризму та індустрії гостинності навичок, що забезпечують їх конкурентоспроможність на ринку nраuі.

Темпи розвитку практично всіх сфер людської діяльності, а так само поглиблення інтеграції на європейському континенті і в світі в цілому обумовлюють актуальність розробки таких освітніх програм, випускникам яких потрібний мінімальний час для адаптачії на робочому місиі. Для досягнення иієї мети навчальним закладам, які готують фахівців для індустрії гостинності необхідна інформачія про критичні показники в очіниі стейкхолдерами програмних результатів освітньої програми. У прочесі дослідження було встановлено критична необхідність оволодіння випускниками «soft skills», найбільш важливими серед яких є лідерство, вміння оперативно вирішувати проблеми, комунікабельність, навички роботи в команді, гнучкість і навички міжособистісного спілкування в мультикультурному, динамічному та багатомовному туристичному середовищі. Порівняльний аналіз ставлення учнів $i$ праиюючих менеджерів до важливості soft skills для працевлаштування та подальшого просування по кар'єрних сходах, до можливості оволодіння окремими soft skills в період навчання в університеті $і$ впливу окремих навичок на адаптаџію молодого фахівия до динамічних умов роботи в сфері туризму і гостинності показав, щчо думки цих двох груп розходяться по ряду питань. Це говорить про те, щчо освітні програми та методи навчання необхідно адаптувати до вимог ринку праці, щчоб випускники ЗВО Украӥни були конкурентоспроможними як на внутріш-ньому, так $і$ на зовнішньому ринках прачі.

Ключові слова: гнучкі навички, туризм, індустрія гостинності.

(С) Савельєва I.B., 2021
УДК 338.48:378

JEL I 20, J 21, L 83

DOI 10.31375/2226-1915-2021-3-115-128

SOFT SKILLS

КАК КЛЮЧЕВЫЕ КОМПЕТЕНТНОСТИ ПЕРСОНАЛА ТУРИСТИЧЕСКИХ КОМПАНИЙ И ИХ РАЗВИТИЕ

ЧЕРЕЗ ОБРАЗОВАТЕЛЬНЫЕ ПРОГРАММЫ В УЧРЕЖДЕНИЯХ ВЫСШЕГО ОБРАЗОВАНИЯ

І.В. Савельєва

д.э.н., профессор, заведующий кафедрой «Предпринимательство и туризм»

Одесский национальный морский университет, Одесса, Украина

Аннотация. В статье рассмотрены наиболее важные для выпускников ЗВО в сфере туризма и индустрии гостеприимства навыки, обеспечиваюшие их конкурентоспособность на рынке труда.

Темпы развития практически всех сфер человеческой деятельности, а так же углубление интеграции на европейском континенте и в мире в целом обусловливают актуальность разработки таких образовательных программ, выпускникам которых требуется минимальное время для адаптачии на рабочем месте. Для достижения этой цели учебным заведениям, которые готовят спеииалистов для индустрии гостеприимства, необходима информация о критических точках в оченке стейкхолдерами программных результатов образовательной программы. В проиессе исследования была установлена критическая необходимость овладения выпускниками «soft skills», наиболее важными среди которых являются лидерство, умение оперативно решать проблемы, коммуникабельность, навыки работы в команде, гибкость и навыки межличностного общения в мультикультурной, динамичной и полиязычной туристической среде. Сравнительный анализ отношения учащихся и работающих менеджеров к важности soft skills для трудоустройства и последующего продвижения по карьерной лестнице, $\kappa$ возможности овладения oтдельными soft skills в период обучения в университете и влиянию отдельных навыков на адаптаиию молодого специалиста к динамичным условиям работьл в сфере туризма и гостеприимства показал, что мнения этих двух групп расходятся по ряду вопросов. Это говорит о том, что образовательные программы и методы обучения необходимо адаптировать к требованиям рынка труда, чтобы выпускники ЗВО Украины были конкурентоспособными как на внутреннем, как и на внешнем рынках.

Ключевые слова: гибкие навыки, туризм, индустрия гостеприимства. 
UDC 338.48:378

JEL I 20, J 21, L 83

DOI 10.31375/2226-1915-2021-3-115-128

\title{
SOFT SKILLS AS KEY COMPETENCIES OF TOURIST ENTERPRISE STAFF AND THEIR DEVELOPMENT THROUGH EDUCATIONAL PROGRAMS IN HIGHER EDUCATION INSTITUTIONS
}

\author{
Iryna Savelieva \\ DSc (Econ.), Professor, \\ Head of Department «Entrepreneurship and tourism» \\ savirina@gmail.com \\ ORCID https://orcid.org/0000-0002-6492-2130 \\ Odessa National Maritime University
}

\begin{abstract}
The article discusses the skills most important for graduates of the HEI in the field of tourism and the hospitality industry, to ensure their competitiveness in the labor market. The pace of development of almost all spheres of activity, as well as the acceleration of integration on the European continent and in the world, determine the relevance of the development of such educational programs, to ensure minimum workplace adaptation time. To achieve this goal, educational institutions that train for the hospitality industry need information about the critical points in the stakeholder assessment of the programmatic results of the educational program. The study identified a critical need for the "soft skills», the most important of which are leadership, the ability to quickly solve problems, communication, teamwork, flexibility and personal interaction in a multicultural, dynamic and multilingual environment. The majority of students believe that soft skills are skills acquired in the workplace to navigate in their environment and good work. This view coincides with the assessment of respondents from another group. Managers also believe that soft skills contribute to better performance of official duties.

The purpose of the survey was also to understand the awareness of students and managers of the hospitality industry about the importance of individual soft skills for work in enterprises that serve tourists and provide hospitality services. The questionnaires were asked to select the most important from the following set: leadership, teamwork, communication, work ethic, problem solving, flexibility and interpersonal skills. A comparative analysis of the attitudes of students and managers to the importance of soft skills for employment and subsequent career advancement, to mastering certain soft skills during the period of study at the university and the function of certain skills to adapt a young specialist to dynamic working conditions in the field of tourism and hospitality showed that the two groups disagree on a number of issues. This suggests that educational programs and teaching methods need to be adapted to the requirements of the labor market.
\end{abstract}

Keywords: soft skills, tourism, hospitality.

Постановка проблеми. Посилення і поглиблення процесів інтеграції, що охоплюють практично всі сфери людської діяльності на європейському континенті, розширення географії туристичних магнітів і маршрутів в глобальному соціальноекономічному контексті зумовлюють зростання привабливості України для іноземних туристів, що, в свою чергу, підвищує актуальність завдання подальшого розвитку вітчизняної галузі туристичних послуг.

Якість і швидкість вирішення цього завдання в значній мірі визначається якістю теоретичної і практичної підготовки фахівців туристичної сфери, зокрема їх здатністю 
DEVELOPMENT OF MANAGEMENT

AND ENTREPRENEURSHIP METHODS ON TRANSPORT, № 3 (76), 2021
РОЗВИТОК МЕТОДІВ

УПРАВЛІННЯ ТА ГОСПОДАРЮВАННЯ

НА ТРАНСПОРТІ, № 3 (76), 2021 орієнтуватися в мультикультурному, багатомовному i різноформатному, 3 точки зору поширення інформації, середовищі.

У сучасному бізнесі, що постійно розвивається, в тому числі і туристичному, людський капітал являє собою ключовий елемент в досягненні організаційних цілей і конкурентоспроможності. Тому випускники, які мають так звані «навички 21 сторіччя», або soft skills (гнучки навички) $[1 ; 2]$, відіграють життево важливу роль в розвитку туристичних організацій і підприємств та забезпечують їм можливість їм перевершувати своїх колег як 3 точки зору конкурентоспроможності на ринку праці, так і з точки зору стійкості на кар'єрних сходах.

Навички 21 сторіччя сьогодні визначаються як критично важливі фактори успіху для співробітників підприємств, завдяки яким забезпечується і підтримується їх кар'єрне зростання. Ці навички включають креативність, критичне мислення, комунікабельність, лідерство, відповідальність та інші соціальні навички в поєднанні з умінням ефективно працювати в команді [1;3].

Основна мета розвитку у студентів спеціальностей, пов'язаних 3 індустрією гостинності, soft skills підготувати для галузі фахівців, які здатні застосовувати знання та компетентності, що виходять за рамки норм контексту освітньої програми [4].

3 огляду на динамічний характер робочого місця фахівця в галузі туризму, що розвивається в умовах швидко мінливих технологій, для університетів першоряднім за важливістю стає завдання випускати гото- вих до роботи фахівців, що володіють навичками творчості та інновацій, спілкування і співпраці, швидкості в пошуку і аналізі інформації, критичного мислення та цифрової грамотності [3; 4]. Такі навички розкривають і вивільняють людське мислення i сприяють більш творчому процесу рішення динамічних проблем туризмy.

Слід відзначити, що ці навички завжди були важливі, але тепер вони набувають іншого значення. Наприклад, комунікація, критичне мислення і відкритість до інновацій необхідні для аналізу великих обсягів інформації $з$ різних джерел, для оперативного прийняття рішень та генерування нових ідей [5; 6]. Тому ці навички вимагають акщенту i додаткового тренування і розвитку, що в подальшому може стати вирішальним фактором успіху на робочому місці.

Однак, не всі студенти, вступаючи до університетів на спеціальності туристичного напрямку усвідомлюють важливість оволодіння soft skills [6; 7]. У результаті вони програють відбори на ринку праці і втрачають час на додаткове тренування навичок, необхідних для конкурентної переваги 3 точки зору роботодавців.

Огляд останніх досліджень та публікацій. Аналіз вітчизняних та зарубіжних досліджень розвитку у майбутніх працівників індустрії гостинності soft skills $[1 ; 3 ; 7 ; 8 ; 9]$ говорить про те, що автори практичні одноголосно схиляються до необхідності і можливості ї розвитку у студентів. Для цього в роботах пропонуються досить ефективні інструменти. Автори досліджень розхо- 
DEVELOPMENT OF MANAGEMENT

AND ENTREPRENEURSHIP METHODS ON TRANSPORT, № 3 (76), 2021
РОЗВИТОК МЕТОДІВ

УПРАВЛІННЯ ТА ГОСПОДАРЮВАННЯ

НА ТРАНСПОРТІ, № 3 (76), 2021 дяться в думках щодо вагомості того чи іншого навику, але в цілому віддають перевагу лідерству, командній роботі та вмінню вирішувати різнорівневі задачі.

Що стосується роботодавців, вони заявляють, що випускники не завжди готові до роботи в нестандартних умовах і закликають університети випускати більш підготовлених і адаптованих до умов праці випускників $[10 ; 11 ; 12]$ з набором навичок і компетенцій, які корисні туристичної компанії [13].

Було встановлено [14; 15], що менеджмент середнього рівня вимагає більш високих лідерських здібностей, таких як делегування повноважень, в той час як комунікативні навички та емпатія більшою мірою важливі на рівні генерального менеджера. При цьому технічні навички не мають великого значення на обох зазначених рівнях.

Постановка задачі. Виходячи 3 цього виникає завдання виявлення найбільш важливих для індустрії гостинності навичок з точки зору студентів і менеджерів, а також зіставлення розбіжностей в сприйнятті їх цінності для двох аналізованих категорій.

Основний матеріал дослідження. Щоб задовольнити потреби ринку праці в секторі гостинності, академічне співтовариство повинно постійно вивчати своїх стейкхолдерів, оцінювати i переглядати навчальну програму, щоб наповнити іiі освітніми компонентами, здатними дати студентам ключові компетентності та навички, необхідні в галузі [16;17].

Слід підкреслити, що, хоча школи готельного менеджменту i програми в галузі гостинності почали працювати над подоланням розриву між здібностями та навичками своїх випускників і вимогами галузі, лише деякі дослідження присвячені характеристикам загальної можливості працевлаштування випускників 3 точки зору студентів і менеджерів[16; 17].

Актуальність результатів проведеного аналізу полягає в тому, щоб допомогти майбутнім фахівцям індустрії гостинності концентрувати зусилля на розвитку певних навичок в процесі освоєння освітніх компонент i досягненні програмних результатів відповідної якості.

В умовах турбулентності навколишнього середовища туристичні підприємства все частіше стикаються 3 необхідністю швидкої адаптації операційної діяльності до технологічних досягнень i тому активно шукають робочу силу з високим рівнем творчості і соціальних навичок для збереження стійкої конкурентоспроможності. Така ситуація на ринку праці спонукає ЗВО до відмови від традиційних практик механічного заучування i повторного використання інформації при навчанні студентів творчості та інноваційним підходам до вирішення проблем та стимулює розвиток методик розвитку у студентів творчих здібностей за допомогою вирішення проблемних кейсів, які потребують процесу мислення вищого порядку.

Існуюча література $[7 ; 13 ; 14]$ передбачає, що творчість і критичне мислення $є$ нероздільними поняттями та здібностями, що ведуть до інновацій, які треба розвивати в процесі навчання в 3 ВО.

На основі аналізу вітчизняних i зарубіжних досліджень [1-6] був складений перелік основних компе- 
тенцій, необхідних сучасній індустрії гостинності. У роботі ми пропонуємо розподілити їх на три категорії: тверді навички (hard skills), гнучкі навички (soft skills) та гібридні (табл.1).

Таблиия 1

Навички працівників індустрії гостинності

\begin{tabular}{|c|c|c|}
\hline Тверді компетенції & Гнучкі компетенції & Гібридні компетенції \\
\hline Аналіз ринку & Коучінг/ розвиток персоналу & $\begin{array}{l}\text { Управління процесом } \\
\text { найму співробітників }\end{array}$ \\
\hline $\begin{array}{l}\text { Оцінка якості туристичного } \\
\text { продукту }\end{array}$ & $\begin{array}{l}\text { Культивація різноманіття } \\
\text { середовища }\end{array}$ & $\begin{array}{l}\text { Критична оцінка інформа- } \\
\text { ції при прийнятті рішень }\end{array}$ \\
\hline Управління витратами & $\begin{array}{l}\text { Уміння вирішувати пробле- } \\
\text { ми клієнтів }\end{array}$ & $\begin{array}{l}\text { Тренування співробітни- } \\
\text { ків для створення єдиного } \\
\text { колективу }\end{array}$ \\
\hline $\begin{array}{l}\text { Розробка маркетингового } \\
\text { плану }\end{array}$ & Делегування завдань & Управління конфліктами \\
\hline Управління бюджетом & $\begin{array}{l}\text { Уміння формувати позитивні } \\
\text { стосунки з клієнтом }\end{array}$ & \\
\hline Методи мотивації персоналу & Сприяння командній роботі & \\
\hline Прогнозування доходів & Лідерські якості & \\
\hline $\begin{array}{l}\text { Прогнозування кадрових } \\
\text { потреб }\end{array}$ & Стресостійкість & \\
\hline Аналіз фінансової звітності & $\begin{array}{l}\text { Управління проєктними } \\
\text { групами }\end{array}$ & \\
\hline $\begin{array}{l}\text { Знання та виконання право- } \\
\text { вих норм }\end{array}$ & Техніка ведення переговорів & \\
\hline Управління ризиками & Швидкість прийняття рішень & \\
\hline Методи активізації продажу & Професійна поведінка & \\
\hline $\begin{array}{ll}\text { Використання } & \text { інформа- } \\
\text { ційних технологій }\end{array}$ & Самопрезентація & \\
\hline $\begin{array}{l}\text { Поведінка у форс-мажорних } \\
\text { обставинах }\end{array}$ & $\begin{array}{l}\text { Використання етики при } \\
\text { прийнятті рішень }\end{array}$ & \\
\hline Управління персоналом & $\begin{array}{l}\text { Ефективна робота } 3 \\
\text { керівниками }\end{array}$ & \\
\hline Управління стійкістю & $\begin{array}{l}\text { Письмові навички } \\
\text { спілкування }\end{array}$ & \\
\hline
\end{tabular}

Джерело: Власна розробка автора

Тверді навички - нard skills це набір професійних навичок та вмінь, пов'язаних з технічною стороною діяльності. Такі навички можна продемонструвати, вони відносяться до обов'язкового функціоналу працівника, вони вказуються умов при при- йомі на роботу та у посадових інструкціях $[7 ; 10 ; 13]$.

Гнучкі навички - soft skills пов'язані не 3 конкретним видом діяльності, а з особистісними якостями працівника, 3 його здібностями 
ефективної взаємодії $з$ колегами, клієнтами та партнерами.

Гібридні навички поєднують риси двох перелічених груп.

У ході дослідження ставлення здобувачів вищої освіти та діючих менеджерів до наявності і необхідності розвитку soft skills у персоналу підприємств індустрії гостинності були опитані студенти спеціальності 242 «Туризм» Одеського національного морського університету та менеджери трьох-, чотирьох- і п'ятизіркових готелів Одеси і Одеської області, гості яких розраховують на високоякісне обслуговування під час свого перебування.
Для аналізу ситуації були зібрані дані, що стосуються сприйняття важливості кожного навику 3 групи soft skills учасниками фокусгруп, виміряного за допомогою п'ятибальною шкали Ликерта, де 1 означає, що респондент категорично не згоден 3 твердженням анкети, 2 - не згоден, 3 - ставиться нейтрально або не визначився 3 відповіддю, 4 - згоден і 5 - повністю згоден.

Розуміння суті soft skills, ïx сприйняття студентами i менеджерами підприємств індустрії гостинності, відображено в табл 2.

Таблиия 2

Оиінка респондентами важливості гнучких навичок

\begin{tabular}{|c|c|c|c|}
\hline Респонденти & Сприйняття респондентами soft skills & $\begin{array}{l}\text { Результати } \\
\text { оцінки, од. }\end{array}$ & Частка, \% \\
\hline \multirow[t]{3}{*}{ Студенти } & $\begin{array}{l}\text { Поєднання набутих навичок роботи з людьми, } \\
\text { соціальні навички, комунікативні навички та } \\
\text { природне вміння спілкуватися. }\end{array}$ & 16 & 20 \\
\hline & $\begin{array}{l}\text { Особисті якості, що дозволяють ефективно та } \\
\text { гармонійно взаємодіяти з іншими людьми. }\end{array}$ & 27 & 33 \\
\hline & $\begin{array}{l}\text { Придбані з досвідом роботи навички } \\
\text { орієнтуватися в своєму середовищі і добре } \\
\text { працювати в галузі }\end{array}$ & 38 & 47 \\
\hline \multirow[t]{3}{*}{ Менеджери } & $\begin{array}{l}\text { Поєднання набутих навичок роботи з людьми, } \\
\text { соціальні навички, комунікативні навички та } \\
\text { природне вміння спілкуватися. }\end{array}$ & 7 & 35 \\
\hline & $\begin{array}{l}\text { Особисті якості, що дозволяють ефективно та } \\
\text { гармонійно взаємодіяти з іншими людьми. }\end{array}$ & 5 & 25 \\
\hline & $\begin{array}{l}\text { Придбані з досвідом роботи навички } \\
\text { орієнтуватися в своєму середовищі і добре } \\
\text { працювати в галузі }\end{array}$ & 8 & 40 \\
\hline
\end{tabular}

Джерело: Власна розробка автора

3 таблиці 2 видно, студенти, що навчаються за спеціальністю «Туризм» у своєї більшості (47 \%) вважають, що гнучкі навички - це придбані на робочому місті навички орієн120 туватися в своєму середовищі та гарна праця. Цей погляд співпадає 3 оцінкою респондентів іної группи. 40 \% менеджерів також вважають, що 
soft skills сприяють кращому виконанню службових обов'язків.

Метою опитування також було зрозуміти обізнаність студентів i менеджерів індустрії гостинності про значимість для роботи на підприємствах, які обслуговують туристів та надають послуги гостинності, окре- мих soft skills. В анкетах було запропоновано вибрати найбільш вагомі 3 наступної сукупності: лідерство, командна робота, комунікація, робоча етика, рішення проблем, гнучкість і навички міжособистісного спілкування. Результати опитування наведені в таблиці 3.

Таблиия 3

Очінка значимості гнучких навичок

\begin{tabular}{|l|l|c|c|}
\hline Респонденти & \multicolumn{1}{|c|}{ Значимість для роботи } & Результат, од. & Частка, \% \\
\hline \multirow{5}{*}{ Студенти } & в індустрії гостинності окремих soft skills & & 6 \\
\cline { 2 - 4 } & Лідерство & 5 & 9 \\
\cline { 2 - 4 } & Вміння працювати в команді & 7 & 14 \\
\cline { 2 - 4 } & Комунікація & 11 & 16 \\
\cline { 2 - 4 } & Трудова етика & 13 & 23 \\
\cline { 2 - 4 } & Уміння вирішувати проблеми & 25 & 6 \\
\cline { 2 - 4 } & Гнучкість & 5 & 20 \\
\cline { 2 - 4 } & Навички міжособистісного спілкування & 15 & 20 \\
\hline & Лідерство & 4 & 10 \\
\cline { 2 - 4 } & Вміння працювати в команді & 4 & 10 \\
\cline { 2 - 4 } & Комунікація & 2 & 20 \\
\cline { 2 - 4 } & Професійна етика & 2 & 10 \\
\cline { 2 - 4 } & Уміння вирішувати проблеми & 4 & 2 \\
\cline { 2 - 4 } & Гнучкість & 2 & 2 \\
\cline { 2 - 4 } & Навички міжособистісного спілкування & 2 & 2 \\
\hline
\end{tabular}

Джерело: Власна розробка автора

3 даних таблиці 3 видно, що значна кількість студентів усвідомлюють комунікативні навички як гнучкі (14 \%), за якими слідують трудова етика (16\%), рішення проблем (23\%) та навички міжособистісного спілкування (26 \%) як найбільш важливі. Проте лише дуже незначна частка здобувачів освіти надають значення навичкам лідерства (6 \%) i гнучкості (6 \%).

Очевидно, таку ситуацію можна пояснити тим, що комунікація, навички вирішення різних проблем i міжособистісне спілкування викори- стовуються студентами в повсякденному житті. У той час, як можливість проявити свої лідерські якості під час роботи в командах надається їм не так часто. Це говорить про те, що навчальні компоненти необхідно наповнити завданнями, що забезпечують здобувачеві всебічний особистісний розвиток.

Низька оцінка студентами необхідності розвитку в собі лідерських якостей та здібностей гнучко реагувати на виклики зовнішнього середовища знижує їх привабливість для роботодавців, які шукають не просто 
співробітників, а амбіційних потенційних керівників.

Відповіді менеджерів підприємств підтверджують такий висновок. Аналізуючи результати їх відповідей можна переконатися в тому, що для роботодавців лідерські якості, вміння працювати в команді і гнучкість в прийнятті рішень $є$ пріоритетними при відборі персоналу.

Цей результат ще раз підтверджує необхідність зміщення акценту програмних результатів освітніх програм у сфері туризму в сторону розвитку у студентів навичок командної роботи в динамічних умовах і можли- вості прояву лідерських якостей, оскільки ці soft skills сприяють швидкій адаптації на робочому місці і реалізації власного потенціалу працівників при досягненні ними прогpecy.

Крім того, були зібрані відповіді студентів і менеджерів сфери гостинності щодо сприйняття ними soft skills 3 точки зору їх корисності в кар'єрі.

У таблиці 4 відображені статистичні дані щодо оцінки двома групами респондентів характеристик гнучких навичок.

Табличя 4

Ставлення респондентів до soft skills

\begin{tabular}{|c|c|c|c|}
\hline Важливість гнучких навичок & Респонденти & Середня & Показники \\
\hline \multirow[t]{2}{*}{ Гнучки навички мають значення для карьєри } & Студенти & 3,9 & \multirow{2}{*}{$\begin{array}{l}\text { t-тест } \\
-4,23476 \\
\text { p-value } \\
6,84 \mathrm{E}-05\end{array}$} \\
\hline & Менеджери & 4,7 & \\
\hline \multirow[t]{2}{*}{$\begin{array}{l}\text { Гнучки навички важливі для отримання } \\
\text { пропозицій роботи }\end{array}$} & Студенти & 3,1 & \multirow{2}{*}{$\begin{array}{l}\text { t-тест } \\
-6,12821 \\
\text { p-value } \\
1,06 \mathrm{E}-07\end{array}$} \\
\hline & Менеджери & 4,5 & \\
\hline \multirow[t]{2}{*}{$\begin{array}{l}\text { Гнучки навички важко засвоїти у порівнянні } \\
3 \text { професійними знаннями }\end{array}$} & Студенти & 4,3 & \multirow{2}{*}{$\begin{array}{l}\text { t-тест } \\
-0,42225 \\
\text { p-value } \\
0,675352\end{array}$} \\
\hline & Менеджери & 4,4 & \\
\hline \multirow[t]{2}{*}{$\begin{array}{l}\text { Гнучки навички неможливо покращити на } \\
\text { робочому місті }\end{array}$} & Студенти & 3 & \multirow{2}{*}{$\begin{array}{l}\text {-тест } \\
0,38072 \\
\text { p-value } \\
0,706186\end{array}$} \\
\hline & Менеджери & 2,1 & \\
\hline \multirow[t]{2}{*}{$\begin{array}{l}\text { Гнучки навички менш важливі, ніж } \\
\text { професійні знання }\end{array}$} & Студенти & 3,6 & \multirow{2}{*}{$\begin{array}{l}\text { t-тест } \\
6,610309 \\
\text { p-value } \\
6,32 \mathrm{E}-07\end{array}$} \\
\hline & Менеджери & 1,6 & \\
\hline
\end{tabular}

Джерело: Власна розробка автора

Для порівняння відповідей студентів і менеджерів був проведений незалежний вибірковий t-тест. За допомогою цього інструменту можливо 
DEVELOPMENT OF MANAGEMENT AND ENTREPRENEURSHIP METHODS ON TRANSPORT, № 3 (76), 2021
РОЗВИТОК МЕТОДІВ

УПРАВЛІННЯ ТА ГОСПОДАРЮВАННЯ

НА ТРАНСПОРТІ, № 3 (76), 2021 встановити, співпадають чи ні погляди здобувачів освіти та менеджерів індустрії гостинності на важливість та значущість гнучких навичок в туризмі. Нашою нульовою гіпотезою буде те, що думки представників обох груп завжди співпадають. 3 табл. 4 можливо зробити висновок, що це не так. Погляди двох груп респондентів збігаються у тому, що soft skills потребують більш зусиль для засвоєння, ніж суто професійні знання, та у тому, що гнучки навички можливо покращити у процесі роботи (помилка у нульовій гіпотезі перевищує $5 \%$ ).

Розбіжність поглядів менеджерів та здобувачів освіти свідчить про те, що освітні компоненти програми навчання повинні включати пояснення щодо важливості soft skills для роботодавці вже 3 першого інтерв'ю.

У таблиці 5 відображені результати опитування щодо мислення та ставлення студентів і менеджерів до важливості soft skills в piзних аспектах професійного та особистого життя.

Незалежні вибіркові t-тести, проведені на основі відповідей про академічну успішність, демонструють, що і менеджери, і студенти вважають, soft skills не важливі для академічної успішності. Таку ж одностайність респонденти проявили у відповідях щодо важливості soft skills для взаємодії з оточенням.

Табличяя 5

Оијінка важливості soft skills в різних аспектах

\begin{tabular}{|c|c|c|c|}
\hline Гнучки навички & Респонденти & Середня & Показники \\
\hline \multirow{2}{*}{$\begin{array}{l}\text { Вміння взаємодіяти } \\
\text { з оточення }\end{array}$} & Студенти & 4,01 & \multirow{2}{*}{$\begin{array}{l}\text { t-тест } \\
-1,83546 \\
\text { p-value } 0,071479\end{array}$} \\
\hline & Менеджери & 4,25 & \\
\hline \multirow{2}{*}{$\begin{array}{l}\text { Просування } \\
\text { службі }\end{array}$} & Студенти & 4,25 & \multirow{2}{*}{$\begin{array}{l}\text { t-тест } \\
-1,83546 \\
\text { p-value } 0,071479\end{array}$} \\
\hline & Менеджери & 4,55 & \\
\hline \multirow[t]{2}{*}{ Пошук роботи } & Студенти & 4,03 & \multirow{2}{*}{$\begin{array}{l}\text { t-тест } \\
-6,11456 \\
\text { p-value } 5,86 \mathrm{E}-08\end{array}$} \\
\hline & Менеджери & 3,85 & \\
\hline \multirow[t]{2}{*}{ Успішність } & Студенти & 3,185185 & \multirow{2}{*}{$\begin{array}{l}\text { t-тест } \\
-1,83546 \\
\text { p-value } 0,071479\end{array}$} \\
\hline & Менеджери & 4,55 & \\
\hline
\end{tabular}

Джерело: Власна розробка автора

У таблиці 6 представлені результати порівняння думок студентів і менеджерів щодо важливості певних soft skills для працевлаштування. 
DEVELOPMENT OF MANAGEMENT AND ENTREPRENEURSHIP METHODS ON TRANSPORT, № 3 (76), 2021
РОЗВИТОК МЕТОДІВ

УПРАВЛІННЯ ТА ГОСПОДАРЮВАННЯ

НА ТРАНСПОРТІ, № 3 (76), 2021

Табличя 6

Важливість гнучких навичок з точки зору респондентів

\begin{tabular}{|c|c|c|c|}
\hline Гнучки навички & Респонденти & Середня & Показники \\
\hline \multirow[t]{2}{*}{ Лідерство } & Студенти & 4,03 & \multirow{2}{*}{$\begin{array}{l}\text { t-тест } \\
-1,98838 \\
\text { p-value } \\
0,051755\end{array}$} \\
\hline & Менеджери & 4,45 & \\
\hline \multirow[t]{2}{*}{ Командна робота } & Студенти & 2,75 & \multirow{2}{*}{$\begin{array}{l}\text { t-тест } \\
-8,80822 \\
\text { p-value } \\
6,88 \mathrm{E}-12\end{array}$} \\
\hline & Менеджери & 4,55 & \\
\hline \multirow[t]{2}{*}{ Рішення проблемних ситуацій } & Студенти & 4,71 & \multirow{2}{*}{$\begin{array}{l}\text { t-тест } \\
6,342563 \\
\text { p-value } \\
1,8 \mathrm{E}-06\end{array}$} \\
\hline & Менеджери & 3,6 & \\
\hline \multirow[t]{2}{*}{ Прийняття рішень } & Студенти & 2,85 & \multirow{2}{*}{$\begin{array}{l}\text { t-тест } \\
-5,5514 \\
\text { p-value } \\
2,54 \mathrm{E}-06\end{array}$} \\
\hline & Менеджери & 4,15 & \\
\hline \multirow[t]{2}{*}{ Управління часом } & Студенти & 3,15 & \multirow{2}{*}{$\begin{array}{l}\text { t-тест } \\
-6,67584 \\
\text { p-value } \\
6,77 \mathrm{E}-08\end{array}$} \\
\hline & Менеджери & 4,35 & \\
\hline
\end{tabular}

Джерело: Власна розробка автора

Студенти висловили сумнів щодо важливості лідерства, командної роботи і навичок раціонального управління часом при працевлаштуванні. Менеджмент індустрії гостинності так само відзначили, що при працевлаштуванні не приділяють великого значення вмінню молодого фахівця управляти своїм часом, хоча цей навик вкрай важливий для ефективної роботи на більш високих посадах. Але в цілому думки щодо навичок командної роботи, лідерства та інших навичок знову розійшлися.

Висновки. Таким чином, на підставі проведеного аналізу ми мо- жемо зробити висновок про те, що студенти і менеджери, які вже працюють в індустрії гостинності, порізному оцінюють важливість різних навичок категоріï soft skills. Ці дві фокус-групи мають різні погляди на вплив того чи іншого навику на успіх працевлаштування та просування по кар'єрних сходах.

Це, в свою чергу, означає, що навчальні заклади, які готують фахівців для туристичної галузі, повинні тісніше взаємодіяти зі своїми стейкхолдерами для того, щоб програмні результати навчання 3 тієї чи іншої 
освітньої програми відповідали вимогам ринку праці.

Турбулентність зовнішнього середовища вимагає від навчальних закладів регулярного перегляду освітніх компонент, необхідних не тільки в поточному бізнес-середовищі, а й актуальних в п'ятирічній перспективі. Студентів необхідно забезпечити можливістю розвинути в собі не тільки технічні професійні навички, а й широкий спектр навичок міжособистісного спілкування.

Крім того, освітні програми повинні формуватися за принципом мультидисциплінарності для того, щоб забезпечити майбутньому фахівцю можливість орієнтуватися у всіх аспектах туристичного напрямку діяльності, а також уміння приймати обгрунтовані i доцільні для підприємства рішення, починаючи вже 3 перших позицій кар'єрних сходів.

\section{СПИСОК ЛІТЕРАТУРИ}

1. Garcia R., Dante Tan R., Florendo J., Santos N. 21st century soft skills in student-centured learning among first-year college students: a comperative study // InternationalJournal of Recent Advances in Multidisciplinary Research. 2020. C. pp.6338-6341.

2. Левкулич B.B. «Soft skills» як важлива складова успіху підприємств готельно-ресторанного бізнесу // III Міжнародна науково-практична інтернет-конференція "Сучасний стан та перспективи розвитку обліку, аналізу та аудиту звітності і оподаткування в умовах євроінтеграції». 2020. URL: https://dspace.uzhnu.edu.ua/jspui/handle/lib/30033.

3. Top10 hospitality and tourism soft skills // Hospitality News \& Business Insights by EHL. 2020. URL: https://blog.ssth.ch/top-10-soft-skills-hospitalitytourism.

4. Мединська С. І. Компетентнісний підхід до підготовки фахівиів галузі туризму та індустрії гостинності для підвищення їх конкурентоспроможності на національному та міжнародному ринках // Вісник університету імені Альфреда Нобеля Серія «Педагогіка та психологія». 2019. C. 64-70.

5. Spowart J. Hospitality students' competencies: Are they work Ready? [Електронний ресурс] // Hum Resour Hosp Tour. 2011: URL: https:// doi.org/10.1080/15332845.2011.536940

6. Tesone Dana, Ricci Rosen Hospitality Industry Expectations of Entry-Level College Graduates: Attitude over Aptitude // European Journal of Business and Social Sciences. 2012. P.140-149. URL: http://www.ejbss.com/recent. aspx ISSN:2235-767X

7. Andrews J., Higson H. Graduate Employability, 'Soft Skills' Versus 'Hard' Business Knowledge: A European Study // Higher Education in Europe. 2008. P. 411-420. 
8. Lippman, L., Ryberg, R., Carney, R., and Moore, K.A. Key «Soft Skills» that foster Youth Workforce Success: Toward a Consensus Across Fields. 2015. URL:https://www.childtrends.org/publications/key-soft-skills-that-fosteryouth-workforce-success-toward-a-consensus-across-fields.

9. Azgarov Abdumutalib Alisher. Tourism education in an emerging digital economy: World experience and perspectives in Uzbekistan International Journal on Integrated Education Volume 3, Issue IX, Sentabr. 2020. P. 146-149. URL: https://media.neliti.com/media/publications/334200-tourismeducation-in-an-emerging-digital-52cbdeae.pdf

10. AbuJbara N., Worley, J.A. Leading toward new horizons with soft skills // On the Horizon. 2018. P. 247-259.

11. Cimatti, B. Definition, Development, Assessment of Soft Skills and their Role for the Quality of Organizations and Enterprises // International Journal for Quality Research. 2016. P. 97-130.

12. Ibrahim, R., Boerhannoeddin, A. and Bakare, K.K. (2017). "The effect of soft skills and training methodology on employee performance», European Journal of Training and Development, Vol. 41. № 4. P. 388-406.

13. Rachmawati, E., Sadira, P., Mufidah, L., Sulistyani, L. Profile of hard skill and soft skill competency in hospitality industry // International Journal of Educational Research Review. 2016. URL: http://www.ijere.com/ frontend/ uploads/submissionfolder/eka-rachmawati/profile-of-hard-skill-and-soft-skillcompetency-in-hospitality-industry-E38pY.pdf

14. Faculty and Student Perceptions of the Importance of Management Skills in the Hospitality Industry // Interdiscip e-Skills Lifelong Learn. 2019. URL: https:// doi.org/10.28945

15. Kennedy, J. Hard skills, soft skills important to career success. 2016. URL:http://www.chicagotribune.com/classified/sns201512021000--tms--careersntp-h bb20151209-20151209-column.htm.

16. Losekoot, E., Lasten, E., Lasten, A., Chen, B. The development of soft skills during internships: The hospitality student's voice // Research in Hospitality Management. 2018. URL: https://doi.org/10.1080/22243534.2018.1553386.

17. Sharma, S., Singh, V. Soft Skills in Tourism - A case study of Tourism Management Graduates // IJRAR. 2020. URL: https://www.ijrar.org/papers/ IJRAR2001190.pdf.

\section{REFERENCES}

1. Garcia, R., Dante Tan, R., Florendo, J. \& Santos, N. (2020). 21st century soft skills in student-centured learning among first-year college students: a comperative study. InternationalJournal of Recent Advances in Multidisciplinary Research. P.6338-6341. 
2. Levkulych, V.V. (2020). "Soft skills» yak vazhlyva skladova uspikhu pidpryyemstv hotel'no-restorannoho biznesu ["Soft skills» as an important component of the success of the hotel and restaurant business]. III Mizhnarodna naukovo-praktychna internet-konferentsiya "Suchasnyy stan ta perspektyvy rozvytku obliku, analizu ta audytu zvitnosti i opodatkuvannya $v$ umovakh yevrointehratsiyi». Retrieved from: https://dspace.uzhnu.edu.ua/ jspui/handle/lib/30033. [in Ukrainian]

3. Top 10 hospitality and tourism soft skills (2020). Hospitality News \& Business Insights by EHL. Retrieved from: https://blog.ssth.ch/top-10-soft-skillshospitality-tourism.

4. Medyns'ka, S.I. (2019). Kompetentnisnyy pidkhid do pidhotovky fakhivtsiv haluzi turyzmu ta industriyi hostynnosti dlya pidvyshchennya yikh konkurentospromozhnosti na natsional'nomu ta mizhnarodnomu rynkakh [Competence approach to training specialists in the field of tourism and hospitality in-dustry to increase their competitiveness in national and international markets]. Visnyk universytetu imeni Al'freda Nobelya Seriya "Pedahohika ta psykholohiya». - Bulletin of Alfred Nobel University Series "Pedagogy and Psychology». P. 64-70. [in Ukrainian].

5. Spowart, J. (2011). Hospitality students' competencies: Are they work Ready? [Електронний ресурс]. J Hum Resour Hosp Tour. Retrieved from: https://doi.org/10.1080/15332845.2011.536940

6. Tesone, Dana \& Ricci, Rosen (2012). Hospitality Industry Expectations of Entry-Level College Graduates: Attitude over Aptitude. European Journal of Business and Social Sciences. P. 140-149. Retrieved from: http://www. ejbss.com/ recent.aspxISSN:2235-767X

7. Andrews, J. \& Higson, H. (2008). Graduate Employability, 'Soft Skills' Versus 'Hard' Business Knowledge: A European Study. Higher Education in Europe. P. 411-420.

8. Lippman, L., Ryberg, R., Carney, R. \& Moore, K.A. (2015). Key "Soft Skills» that foster Youth Workforce Success: Toward a Consensus Across Fields. Retrieved from: https://www.childtrends.org/publications/key-soft-skills-thatfoster-youth-workforce-success-toward-a-consensus-across-fields.

9. Azgarov Abdumutalib, Alisher (2020). Tourism education in an emerging digital economy: World experience and perspectives in Uzbekistan International Journal on Integrated Education Volume 3, Issue IX, Sentabr. P. 146-149. Retrieved from: https://media.neliti.com/media/publications/ 334200-tourism-education-in-an-emerging-digital-52cbdeae.pdf

10. AbuJbara, N., Worley, J.A. (2018). Leading toward new horizons with soft skills. On the Horizon. P. 247-259.

11. Cimatti, B. (2016). Definition, Development, Assessment of Soft Skills and their Role for the Quality of Organizations and Enterprises. International Journal for Quality Research. P. 97-130. 
12. Ibrahim, R., Boerhannoeddin, A. \& Bakare, K.K. (2017). «The effect of soft skills and training methodology on employee performance». European Journal of Training and Development. Vol. 41. № 4. P. 388-406.

13. Rachmawati, E., Sadira, P., Mufidah, L. \& Sulistyani, L. (2016). Profile of hard skill and soft skill competency in hospitality industry. International Journal of Educational Research Review. Retrieved from: http://www.ijere. com/ frontend/ uploads/submissionfolder/eka-rachmawati/profile-of-hardskill-and-soft-skill-competency-in-hospitality-industry-E38pY.pdf

14. Faculty and Student Perceptions of the Importance of Management Skills in the Hospitality Industry (2019). Interdiscip e-Skills Lifelong Learn. Retrieved from: https://doi.org/10.28945

15. Kennedy, J. (2016). Hard skills, soft skills important to career success. Retrieved from: http://www.chicagotribune.com/classified/sns201512021000-tms--careersntp - h bb20151209-20151209-column.htm.

16. Losekoot, E., Lasten, E, Lasten, A. \& Chen, B. (2018). The development of soft skills during internships: The hospitality student's voice. Research in Hospitality Management. Retrieved from: https://doi.org/10.1080/22243534. 2018. 1553386.

17. Sharma, S. \& Singh, V. (2020). Soft Skills in Tourism - A case study of Tourism Management Graduates. IJRAR. Retrieved from: https://www.ijrar.org/ papers/IJRAR2001190.pdf.

Стаття надійшла до редакиії 18.06.2021

Посилання на статтю: Савельсва I.B. Soft skills як ключові компетентності персоналу туристичних підприємств та їх розвиток через освітні програми у закладах вищої освіти // Розвиток методів управління та господарювання на транспорті: Зб. наук. праць, 2021. № 3 (76). C. 115-128. DOI 10.31375/2226-1915-2021-3-115-128.

Article received 18.06.2021

Reference a JournalArtic: Savelieva, Iryna. (2021). Soft skills as key competencies of tourist enterprise staff and their development through educational programs in higher education institutions. Development of management and entrepreneurship methods on transport. 3 (76), 115128. DOI 10.31375/2226-1915-2020-3-115-128. 